\title{
LESSONS (NOT) LEARNED FROM THE CLIMATE CHANGE ADAPTATION POLICY: QUALITATIVE RESEARCH ON THE CASE OF FLOODS IN WESTERN BALKAN COUNTRIES
}

\author{
Jelena Pudak
}

University Department of Croatian Studies
University of Zagreb
Borongajska cesta 83d, 10000, Zagreb
e-mail: jelena.pudjak@pilar.hr

\begin{abstract}
In this paper we present the findings of our qualitative research on adaptation to climate change within the context of the major floods that hit countries in Central and South-Eastern Europe in 2014. Adaptation here refers to the response of any given social system regarding existing and expected impacts of climate change and extreme climate events. The effectiveness of the response depends on how vulnerable or how resilient a particular system is, and this includes not only technical and biophysical aspects, but also social, cultural, political and economic ones. We conducted empirical research in order to describe how actors in environmental governance structures in three countries - Bosnia and Herzegovina, Croatia and Serbia - viewed the climate change adaptation process, and whether they recognized climate change as a trans-sectoral problem during all the phases of the 2014 flood crisis. The results show that even though most interviewees are aware of the connection between climate change and the 2014 floods, they are unable to properly address these kinds of crises. Given that in all three countries climate mitigation and adaptation measures are divided between different ministries and departments, which are not complementary, this lack of interconnectedness is thus reflected in the interviewees' observations.
\end{abstract}

Keywords: climate change adaptation, qualitative research, western Balkans

\section{INTRODUCTION}

Over the last decade the debate on climate change has largely shifted from mitigation which deals with causes, to adaptation which deals with the consequences of climate change. This shows that not only the growing awareness about the imminent consequences of the global rise in temperature, but also the devastating effects already taking place around the globe are a direct result of the inefficiency of implementation of the 1997 Kyoto Protocol mitigation measures. Extreme climate events such as massive floods are usually caused by major cyclones, and as such are not unusual; nevertheless, their occurrence and intensity have increased due to the global rise in temperature. The 
year 2014 was marked by such an extreme event, a flood that hit nine countries in Central and South-Eastern Europe, leaving tens of thousands of casualties in its wake and 12 billion Euros in damage (Jongman et al., 2014). According to Jongman's projections, extreme streamflows correlate among all European river systems, and damages caused by extreme floods will double by mid-century (Jongman et al., 2014). ${ }^{1}$ Croatia and its neighboring countries were affected by extreme flooding in 2014 and the research presented in this paper aims to seek out the response of authorities to this extreme climate event.

The consequences of extreme weather conditions largely depend on the level of vulnerability and exposure to such conditions (Cardona et al., 2012). Also, risk depends on economic, social, demographic, geographic, cultural and other factors, and a high level of vulnerability is the result of former developmental processes, especially those related to environmental protection, demographic and urban planning, inefficient governance, as well as poor living conditions, and a lack of access to resources for the poorest segments of the population (Cardona et al., 2012; Stocker et al., 2013).

In the abovementioned conditions, adaptation can only be efficient if the entire context is taken into consideration during the formulation of policies and measures, and sustainable development which aims at reducing the vulnerability and increasing resilience is implemented at the same time. Choosing the appropriate strategies of adaptation and disaster management depends on the decision-making process, thus it is of utmost importance not only to use quantitative methods for risk and vulnerability assessment, but also conduct qualitative research so as to explain and describe all the aspects of vulnerability and local specifics for which the adaptation policies are being devised.

After a short review of the basic terms and definitions related to the concept of adaptation to climate change and associated concepts, some recent research on adaptation processes, both in developed and developing countries will be briefly discussed. The second part of this paper deals with the results of the qualitative research conducted in three countries, Bosnia and Herzegovina, Croatia, and Serbia. The research aims to describe the critical points within the sector of environmental governance in the context of setting up an institutional capacity to respond to consequences of climate change. After the results are presented, a brief discussion about the key points and limitations of the research will ensue, followed by the conclusion.

1 The IPCC Fifth Assessment Report on Climate Change (2013) states that human influence on global warming and climate change is clear, and the scope of climate change is unprecedented; there are recent observable consequences on human and environment systems and extreme weather has been observed as "an increase in warm temperature extremes, an increase in extreme high sea levels and an increase in the number of heavy precipitation events in a number of regions" (Stocker et al., 2013:7). If current trends continue there will be an increase of "severe, pervasive and irreversible impacts for people and ecosystems. Limiting climate change would require substantial and sustained reductions in greenhouse gas emissions which, together with adaptation, can limit climate change risks" (Stocker et al., 2013:8). 


\section{BASIC TERMS AND DEFINITIONS}

According to Moser and Ekstrom (2010), adaptation refers to changes within the socioecological systems that happen as a response to observed or expected impacts of climate change within the context of interaction with non-climate change. Actions and strategies of adaptation may be short-term or long-term; they may be transformative and aim at multiple changes within a system (and not just fulfill the goals related to climate change), or they may more or less be successful in alleviating damage or making the most of positive prospects (Moser and Ekstrom, 2010). Giddens (2009) compares adaptation to the precautionary principle, since he sees adaptation as a preventive action which aims to hinder or constrain future risks. Kates et al. differentiate between incremental and transformative adaptation, with incremental adaptation being the extension of existing actions and strategies for damage mitigation and increase of the benefits of climate variability (Kates et al., 2012). The authors also distinguish between three types of transformative adaptation: actions and strategies of adaptation which are conducted on a large scale (large space and high intensity); actions and strategies of adaptation which are new to a particular resource system or region; and actions and strategies of adaptation which change the space and move locations (Kates et al., 2012).

Adaptation in any of the aforementioned cases is not merely technological; it includes behavioral changes of both individuals and communities, changes in societies, institutions and decision-making processes, as well as changes in the distribution of resources (Adger et al., 2009; Giddens, 2009; Kates et al., 2012; Moser and Ekstrom, 2010).

Adaptation strategies largely depend on the vulnerability of a society to climate change, and its resilience to internal and external stressors. Within the context of risk management, vulnerability refers to the level of physical resilience of the built environment (Stocker et al., 2013). Newer theoretical and empirical research connects vulnerability and associated concepts (adaptation and resilience) with the characteristics and complex interaction between social and environmental processes (Adger et al., 2009; Davoudi, 2012; Funfgeld and McEvoy, 2012; Parry et al., 2007; Stocker et al., 2013; Shaw, 2012). In relation to climate change, vulnerability is usually defined as "the degree to which systems are susceptible to, and unable to cope with, adverse effects of climate change, including climate variability and extremes. Vulnerability is a function of the character, magnitude and rate of climate change and variation to which a system is exposed, its sensitivity, and its adaptive capacity" (Parry et al., 2007:27).

Vulnerability mostly depends on a specific type of risk, nevertheless, some factors, such as poverty, lack of social networks, marginalization, unequal access to resources, etc., increase the level of vulnerability regardless of the risk type (Brooks, 2003). Analyzing the interconnection between the standard of living and vulnerability, Cannon (2006) argues that high vulnerability is largely the result of an inadequate developmental process. Thus, the level of vulnerability depends upon the conditions in which the individuals live, which in turn are the result of historical, cultural, political, economic and ecological processes (Adger et al., 2009; Brooks, 2003; Cardona et al., 2012). When 
researching the climate change impact, it is therefore very important to keep in mind the "hidden" causes of vulnerability and capacity of adaptation, instead of focusing only on technical aspects (Cardona et al., 2012).

On the other hand, resilience, or resilience governance, can be seen as a self-reflexive understanding of the role societies have in interaction with nature in so far as governance is no longer a matter of intervening in problems that are seen as external to society, but as a part of it (Chandler, 2014). That kind of approach challenges the (neo)liberal top-down understanding of governance with its highly regulatory and interventionist regimes, where the market is idealized to be able to indirectly make the complex interactions of socio-economic life accessible (Chandler, 2014). Also, in the age of Antrophocene, when humanity is recognized as a global geological force, resilience is seen as a conceptual framework that seeks to sustain the vital eco-services that make social life possible, and where politics is in fact reactive in responding to and managing the consequences of human actions (Grove and Chandler, 2016).

In his epistemological and ontological analysis, Chandler (2014:57) defines resilience as a radically distinctive approach on how policy intervention is perceived to operate - policy failure is seen as a "learning opportunity with regard to the systemic process of unintended consequences and side-effects in a complex world, where failure enables policy-makers to learn from the revelation of these concrete and emergent interconnections".

Concepts such as adaptation, vulnerability and resilience to climate change are inseparable from the concept of risk. Risk and / or disaster management is the sector (within both the public administration and the expert community) which at least partially deals with adaptation and associated concepts. O'Brien et al. (2006) argue that in order to have an efficient adaptation to climate change, a holistic approach to disaster management is needed, based on building up the resilience of communities and promoting sustainable development. ${ }^{2}$ On the other hand, Thomalla et al. (2006), by analyzing the similarities and differences between the approaches of two expert communities to climate extremes, namely the adaptation approach to climate change (climate policy) and the disaster management approach, reveal that these communities have different perceptions of the time scale regarding particular risks, especially in relation to perceived uncertainty in projections. The imminent impact of climate change is often discussed in terms of uncertainty instead of accurate projections for the future; thus, the disaster management approach focuses on a wide range of risky events, climate extremes being just a part of them. The prime focus of this approach is the immediate danger, short term response to particular stressors via structural measures which guarantee the physical safety of individuals, property and critical infrastructure. In contrast, climate policy in the past had to deal with unspecified risks in the future, but more recently adaptation policy focuses on vulnerability to climate

2 Jessica Mercer argues in favour of disaster risk reduction; she states that climate change adaptation is more narrow in definition, and that it falls under the broader concept of disaster risk reduction which includes a broad analysis of vulnerability aspects, climate being just one of them (Mercer, 2010). 
extremes and the current consequences of climate change (Thomalla et al., 2006). Both approaches have been developing independently within these communities and have been separated within public administration bodies in most countries. While disaster management falls under Civil Protection, climate policy belongs to Environmental Protection and Management (Thomalla et al., 2006).

From a social ecology perspective, it is important to emphasis human activity, better yet, the interaction between social structures and physical environment in creating risk. Social structures and ecosystems interact in space and time, creating specific vulnerabilities within joint human-environment systems (Turner et al., 2003; Nkoana et al., 2018). To understand and reduce the vulnerability of communities, an analysis of the aforementioned interaction between complex human-environment systems and the way it shapes the vulnerability is needed, as well as an analysis of external economic and political forces that influence the adaptation capacity (Turner et al., 2003). ${ }^{3}$

\section{BARRIERS TO ADAPTATION - CAN BOTH THE RICH AND THE POOR ADAPT?}

It has already been mentioned that social factors such as poverty, access to resources, and various developmental processes have a huge impact on the level of vulnerability to extreme events. This is true for both developed and developing countries - the capacity for adaptation depends on the development curve of each country (Mirza, 2003). However, developed countries are able to invest in infrastructure and adaptation strategies for possible future risks, while developing countries usually invest in recovering from the disasters that have already happened. Thus they are not capable of investing in adaptation capacity; rather they are caught in the vicious circle of falling into financial debt in order to repair damages from past extreme events (Mirza, 2003). ${ }^{4}$ In this context, O'Brien and Leichenko's (2003) concept of "winners" and "losers" applies to the effect of climate change. The authors approach the analysis from two viewpoints; the first viewpoint refers to the natural, geographic division between winners and losers and relies on social Darwinism; the second viewpoint refers to a sociopolitical division which relies on political ecology. Although opposing concepts in theory, the authors believe that when it comes to climate change these two concepts coexist in developing

\footnotetext{
3 In their analysis, the authors tested the vulnerability framework of the Research and Assessment Systems for Sustainability Program (http://sust.harvard.edu) which recognises joint human-environment systems and the ways in which these systems can influence the response to risk and vulnerability, enabling assessment of the stakeholders' capacity to access biophysical and social capital. Case studies were conducted in south Yucatan, north-eastern Mexico and in the Arctic (Turner et al., 2003).

4 Mirza also demonstrates that extreme weather events pose more of a risk for developing countries, and that annually they have 20 times more financial loss per capita than developed countries. Therefore, in order for developing countries to build resilience, it is crucial that developed countries invest in the necessary infrastructure and adaptation capacity of developing countries (Mirza, 2003).
} 
countries (O'Brien and Leichenko, 2003). Developing countries and underdeveloped countries are largely situated in areas where high climate variability and climate extremes are expected, moreover, inequalities on the global and local level are generated by sociopolitical factors, and reveal social construction of vulnerability. ${ }^{5}$ Through an analysis of rural communities in sub-Saharan Africa, Nkoana et al. (2018) conclude that the prerequisite for efficient adaptation is engaging the community using the livelihoods approach; respecting the cultural aspects as well as the local champions; identifying the most vulnerable stakeholders; and implementing a two-way communication instead of a one-sided information sharing approach.

Winners and losers can be found within societies as well; even in developed countries, poor people, women and children are the most vulnerable groups who suffer more losses and have less adaptation capacity (Mirza, 2003; O’Brien and Leichenko, 2003). Also, some authors suggest that implementation processes are inefficient even in developed countries (Adger, 2003; Ford et al., 2011). Common conclusions point to the sporadic implementation of adaptation strategies, mainly on the local level and most commonly as a reaction to immediate extreme events. Little attention is given to vulnerable segments of the population, which are often excluded from disaster management decisionmaking processes (Adger, 2003; Ford et al., 2011). A solution to this problem may be seen in social capital and collective action, where informal organizations and civil society play a key role. When vertical networks between civil society and the government exist, new institutional frameworks can develop, and a synergy of the social capital which promotes adaptation capacity is created (Adger, 2003). On the other hand, broad participation in the decision-making process carries the risk of conflicted interests that are embedded in relations of power, and therefore it creates tensions between overly inclusive participation and anticipatory adaptation strategies which can be ruinous for both participation and adaptation (Few et al., 2007).

To better understand the barriers to adaptation, it is important to apply a transdisciplinary approach to climate change adaptation, which includes technical and physical barriers, as well as social barriers to adaptation. In order to define these barriers, it is necessary to understand the way a particular society is organized, what is the common knowledge, which are the shared values and what are the relationships between the individuals, institutions and the government in that society like; barriers are thus endogenous, they come from society, they are constructed by society and its prevalent values, knowledge, risk perception and culture (Adger et al., 2009). Moser and Ekstrom (2010) analyze in detail the barriers to adaptation through three stages of adaptation: understanding, planning and managing. ${ }^{6}$ Actors who choose and implement the adaptation strategies have a key role, and the real intent to carry out the strategies represents

\footnotetext{
5 Having analysed three developing countries case studies, Mirza (2003) came to the same conclusion as O'Brien and Leichenko (2003); besides being situated in geographically vulnerable areas, other factors influence the level of vulnerability of developing countries: economic and social conditions, political and institutional mechanisms, distribution of resources, and adaptation capacity.
} 
the first barrier. Within the adaptation context, the role of the government and society is also important; public perception of rights, available resources, licenses and laws, political climate and social norms all play a role (Moser and Ekstrom, 2010). Most authors agree that for efficient adaptation to take place, building up the resilience of a society is vital (Adger, 2003; Füssel, 2007; Giddens, 2010). Poor planning of the ways in which the public can participate, and a lack of culturally sensitive measures suited for the local context can also act as a barrier (Nkoana et al., 2018).

Some barriers are very common according to Moser and Ekstrom's research (2010), and appear at all stages, from planning to implementing of adaptation strategies. They include leadership, which is of utmost importance in the initial stages of adaptation process. During the stages of planning and managing, which depend on scientific evidence, resources have come up as one of most common limitations; not just in the form of finance, but also in the form of information, technology, expert personnel and time. Communicating and informing stakeholders and the general public about the issues, solutions and implications are also very important for efficient adaptation programs, and can also become a barrier. Finally, values and beliefs have an effect on individuals' perception and interpretation of risk, and their decision-making process (Moser and Ekstrom, 2010).

Furthermore, it is important to keep in mind that even the most efficient adaptation is not risk-free since climate change is unpredictable, thus adaptation cannot be a substitute for further development of mitigation measures (Füssel, 2007).

Keeping in mind the discussed process of adaptation strategies development, as well as the barriers that show up, in the second part of this paper we will present the results of the qualitative research conducted in three countries in the western Balkans that had been affected by the extreme floods in 2014. Through the research we will describe the political response to the floods, as seen by the stakeholders, and provide a comparative analysis of the differences and similarities between the three countries.

\section{EMPIRICAL RESEARCH}

In May 2014 the major flood that affected parts of eastern Croatia, north-eastern Bosnia and western Serbia was caused by increased precipitation over a period of several days, but also due to an exceptionally "wet" season, which caused a rapid rise of water levels in the Sava River and its tributary rivers in the middle and lower fluvial region. The flooding caused immense material damage, human causalities including death, and

6 In these three stages of analysis, the authors also include the general context in which the stakeholders act, their actions as well as the object of their actions. The stage of understanding includes detecting problems, understanding and using the information, and redefining the problems. The planning stage includes developing adaptation options, evaluating the options and choosing between options. The managing stage includes the implementation of these options, and monitoring of the outcomes and evaluation (Moser and Ekstrom, 2010). 
short-term displacement of the population. However, not all three countries were affected equally. In Croatia around 38,000 persons were affected by the flooding, two persons died and more than 13,000 were evacuated from their homes; in Bosnia more than a million people were affected by the floods, 25 people died and over 90,000 were evacuated; in Serbia the flooding affected the largest number of people, 1.6 million, with 23 people dead and 32,000 evacuated (Župarić-Iljić, 2017). Besides human suffering, the flooding caused major infrastructure damage (including electric network, sewage and water supply), loss in cattle and agricultural assets (Župarić-Iljić, 2017).

In his case study, Župarić-Iljić (2017) also states that the affected areas were underdeveloped, and the inhabiting population was highly vulnerable in terms of economic, social and demographic parameters, including high unemployment rates and a high number of those living on social welfare. ${ }^{7}$

Empirical research was conducted to describe the environmental governance structures (positioned in the triangle between accountable ministries, agencies, and cross-sectoral bodies) in the three countries (Bosnia and Herzegovina, Croatia, and Serbia) with a focus on recognition of climate change as a trans-sectoral problem in all phases of the 2014 flood crisis. The focus of this comparative qualitative research was the relationship between existing (and missing) governance structures relevant in this field and the need for a policy reform that would be grounded in recognizing climate change as an external challenge which requires coherent and coordinated political action both on the mitigation and the adaptation side.

Although floods are not exclusively and solely related to climate change, their increased and destructive occurrences sufficiently demonstrate the lack of state and local capacity to tackle negative climate change impacts, including floods, which could be substantially reduced through adequate policy reform and its consequent implementation. The goal here is not to try and make any predictions as to the number or type of actors (or their roles) needed for adequate reform, rather to investigate how the actors included in the adaptation process and risk management evaluate those processes themselves.

The main research questions that this paper aims to answer are whether there is a recognition of the connection between the 2014 floods and climate change on behalf of policy makers and regarding climate policy and extreme weather management; whether the 2014 flood crisis brought about any modifications in climate policies; and what the obstacles and opportunities for better adaptation measures are.

The aim of this study is to detect the most fragile points in the field of environmental (and overall) governance regarding climate adaptation policy, and why adequate conditions for the implementation of these policies have not been developed (if such is the case).

7 In Croatia and Bosnia the areas that were affected by the floods had also suffered great devastation during the war at the beginning of the 1990s, and some areas never fully recovered. Also, in Serbia, among the affected population were asylum seekers from African and Asian countries (Župarić-Iljić, 2017). 


\subsection{Sampling and methodology}

Semi-structured interviews were conducted within the research. Conversations included the following topics: recognition of manifestations of climate change in the particular country; development of climate policy in regard to decisive events; management of flood crisis and the role of public administration; what could be, or could have been done better. ${ }^{8}$ This was the source of information and data for analyzing and understanding of attitudes and recognition of extreme weather events as manifestations of climate change that need to be tackled with adequate policies.

Due to a highly specialized research topic, we opted for a deliberate sample consisting of relevant agents. The sample consisted of relevant stakeholders, primarily ministries, agencies and funds, but also expert community and civil society organizations; however, not equally represented in all three countries. Interviews were conducted in each country using an identical questionnaire, adaptive to specific national conditions, and designed to meet the standards of a comparative study. Out of 40 contacted stakeholders, 29 agreed to participate in the research; 12 from Croatia, 8 from Bosnia and Herzegovina, and 9 from Serbia.

The data analysis was conducted via Atlas.ti. The procedures that were used in the analysis are simultaneous data collection and analysis, multilevel coding, comparative analysis and conceptual analysis. In this way we have inductively developed some basic concepts that helped us answer the research questions. This type of data processing was chosen so as to best achieve the aim of the research and understand the social behavior within the climate change policy context. Through the analysis we developed codes on several levels of abstraction and developed thematic networks through which we interpreted the results (Charmaz, 2000; Corbin and Strauss, 1990; Ryan and Bernard, 2000). Climate change policies provide the necessary framework which guarantees the requirements have been met for de facto reduction of greenhouse gas emissions (mitigation), and for adequate dealing with extreme weather events (which have been recognized as a part of the same problem, i.e. climate change). So far regional climate policy has been quite inefficient with respect to both mitigation and adaptation. Therefore, we can say that the social contribution of this paper consists of answering some of the crucial questions about the relationship between climate change and disaster management. The need for recognition of this relationship is becoming more and more apparent, as we

8 There were 12 fundamental open-end questions which were optionally modified and / or expanded to correspond to the certain national context and expertise of an interviewee. Interviews were taped with the consent of the interviewees, and the audio recordings transcribed. The authors of this paper conducted the interviews. During transcribing and analysing the data, and writing of the report, the anonymity of the participants was preserved by creating codes for each interviewee instead of using their real names. In citing the interviewees throughout this paper, we used those same codes consisting of the first letter of a country ( $\mathrm{H}$ for Croatia, B for Bosnia and Herzegovina, and S for Serbia), and a number. The interviews were conducted during July and September of 2016. 
face many extreme weather events throughout Europe. The scientific contribution of this paper also lies in the effort to understand social, namely governmental, relations to specific climate change issues (i.e. extreme weather events) in the sociological context.

\subsection{Research findings}

Throughout the questionnaire we tried to connect climate change and the 2014 floods, as well as the overall climate policy and crisis management (concerning flood crisis), sometimes by directly connecting the issues in the same question, and sometimes by separating the two. However, the interviewees' tendency for the most part was to separate climate policy and flood management in their answers, connecting the two issues only when talking about adaptation. This means interviewees mostly talked about systemic obstacles to efficient climate policy, or the state apparatus' reaction in the face of extreme weather events, but only a few interviewees talked about the need for adaptation measures in the form of risk management within climate policy. None mentioned the mitigation role in preventing and / or reducing extreme weather events. This is shown below in the graphic model of our analysis. The final number of codes (descriptive and interpretative) were grouped in three thematic domains: climate policy, flood management and private / public sector's role.

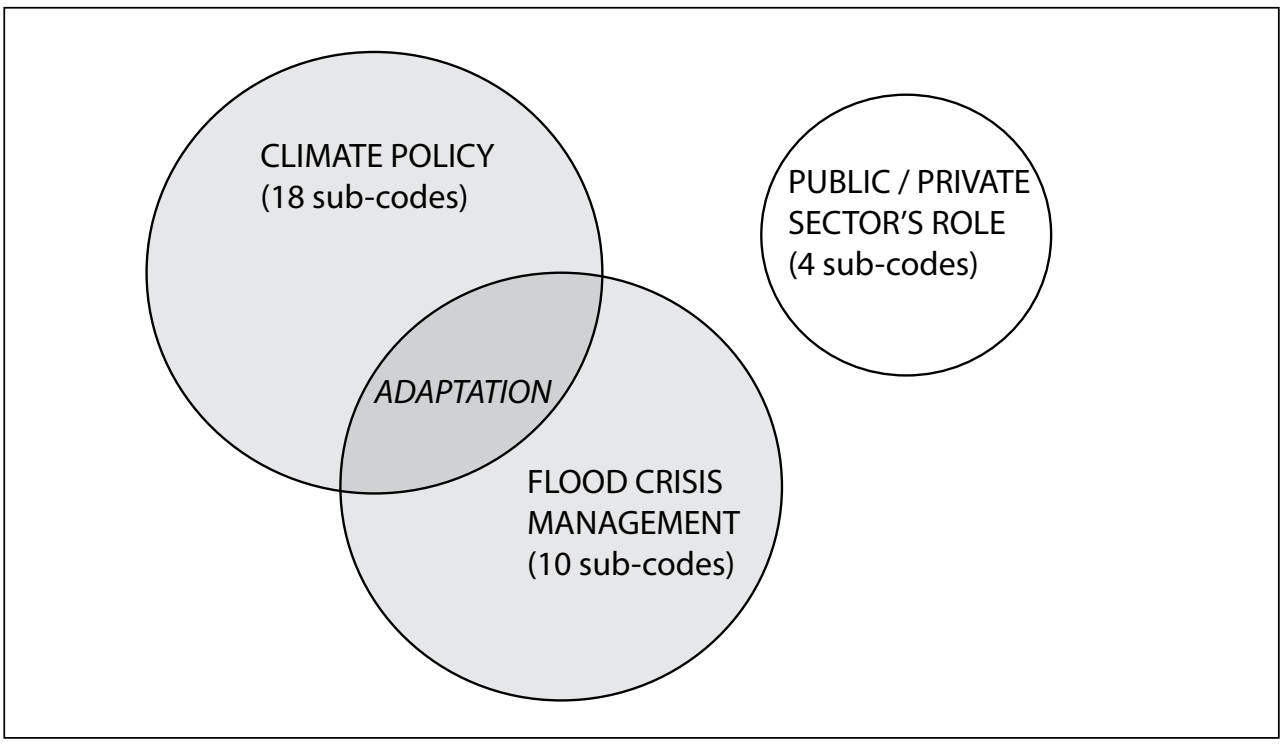

Figure 1. Three thematic domains

While the "climate policy" and "flood crisis management" domains partially overlap, the "private / public sector's role" domain is unconnected to either of the other two. Nonetheless, it was important to include it in the results, since the interviewees considered it to be a somewhat important topic. 
In the following sections we will present each thematic domain and its sub-codes with respect to the differences / similarities between the countries. ${ }^{9}$

The thematic domain "climate policy" holds 18 sub-codes that form a network through which interviewees were able to describe their views on the climate policy in their country, the problems with it, and whether they saw any connections between climate policy and the 2014 flood crisis (see Table 1).

Table 1. Climate policy domain: appearance of codes in country ${ }^{10}$

\begin{tabular}{|l|l|}
\hline \multicolumn{1}{|c|}{ CODES } & \multicolumn{1}{|c|}{ APPEARANCE IN COUNTRY } \\
\hline Public department inertness & Bosnia, Croatia, Serbia \\
\hline Influence of infrastructural projects & Bosnia, Croatia \\
\hline Corruption & Bosnia, Croatia, Serbia \\
\hline Economic and political crisis & Bosnia, Croatia, Serbia \\
\hline Negative selection in public administration & Bosnia, Croatia \\
\hline There is no climate policy & Bosnia, Croatia \\
\hline Poor human capacities & Bosnia, Croatia, Serbia \\
\hline Lack of integrative approach* & Bosnia, Croatia, Serbia \\
\hline Incompatibility of key documents* & Croatia, Serbia \\
\hline Political censorship & Croatia \\
\hline Politics doesn't use science* & Bosnia, Croatia, Serbia \\
\hline Need for separate department for climate policy & Bosnia, Croatia, Serbia \\
\hline Problems on local level* & Bosnia, Croatia, Serbia \\
\hline Growing government capacities for climate policy & Croatia, Serbia \\
\hline International influences & Bosnia, Croatia, Serbia \\
\hline Public interest negligence & Croatia \\
\hline
\end{tabular}

* Codes that refer to climate adaptation policy - where the climate policy domain and flood crisis management domain overlap

For the most part, when asked to describe the development of the climate policy in their country and the events crucial for the formation of climate policy, interviewees would say that the climate policy was mostly steered by pre-accession negotiations with the

9 The final number of codes was determined by the criteria of groundedness and density; only those frequently appearing and well connected with the other codes.

10 More detailed tables on primary documents / codes data can be found at the end of this paper in Appendix 1. 
EU. They see the climate policy in their countries as poorly developed and unrelated to the specific needs and abilities of each country. Some would say that "there is no climate policy at all". While describing some of the key elements a climate policy should have, at the same time they would argue that these precise elements are missing from the domestic climate policy, as this quotation illustrates:

B2: "I don't see any real climate policy. The fact that sector strategies and plans are being developed without any consideration for climate change... energy, agriculture, forestry, water management, transport, construction etc. are all being developed in such a manner. So far, some projects have been developed by the governments in regard to energy efficiency, but for the most part, climate change is just a phrase used from time to time, no serious attention has been given to it."

There are a few possible explanations for this. Interviewees see policy makers as uninterested and lacking both knowledge and responsibility to deal with or prioritize climate change issues. The prevailing stance is that there is a negative selection of personnel in public administration (clientelism) which brings uninterested and ignorant individuals to the decision-making process; individuals who hold positions through political lines and not expertise. The connection can be made with the obstacle that Moser and Ekstrom (2010) detect in the leadership segment; the lack of individuals who can initiate processes at a critical time and motivate all included parties; but also in the resources segment, especially in regard to expert personnel. Also, one of the most discussed obstacles is the lack of an integrative approach to climate policy - almost all interviewees, in each country, would say there is no cooperation amongst public administration sectors and different ministries on climate issues. Climate change mitigation in each country falls under ministries for environmental protection, which are rated as the least influential departments in all governments. We can illustrate the latter with the following quotation:

H5: "We are preparing an adaptation strategy at the ministry level, but actually other ministries, such as the health department or internal affairs... should all take part in it and create a common strategy. (...) Instead we just print more and more papers for the ministry that has no resources to implement that strategy."

Associated with the latter code ("lack of integrative approach") is the incompatibility of key documents, strategies and measures of climate politics. The lack of cooperation amongst different government and public bodies results in strategies with opposite goals and visions, and sometimes opposite measures regarding mitigation and adaptation policies. Such is the case in Croatia, whereas interviewees from the other two countries do not make mention of it. This has to do with the state and scope of climate policy in different countries, since Croatia is the only EU member out of the three, and thus has had to implement an EU legislative framework concerning climate change and has taken over EU goals for emission reduction. The other two countries barely have any measures or documents that could be considered a climate policy. In all 
countries the interviewees see government and public administration bodies as inert, meaning there is a large administration and highly hierarchical structure that disables quick and efficient decision-making. One interviewee from Croatia describes it in the following quotation:

H2: "Government administration is sluggish. When you detect the problem, you need about four years to adjust the organization, and then when you have made the adjustments, you ask for a couple of more years to develop necessary competences, and then you face yet another problem..."

Interviewees also talked about the lack of capacities, namely human resources (regarding both number and knowledge) on the local level to participate or create measures for local resilience in the face of climate change. There were even reports on local resistance to participate in the mitigation process, due to the perception that it would be too expensive to implement some of the measures. This again corresponds with the barriers Moser and Ekstrom see in the human resources segment, but also with barriers detected by Adger et al. (2009) regarding social and individual factors in the perception of risk. Corruption is only rarely mentioned by the interviewees.

Although some authors state that cooperation with scientists is a prerequisite for successful adaptation (Füssel, 2007; Cardona et al., 2012), interviewees in the three countries feel that decision makers do not use scientific evidence and predictions to create an adaptation (or overall climate) policy, but least so in Croatia. Croatia again stands out because of the relatively developed climate policy and orderly cooperation of risk management institutions with science institutions. On the other hand, the law in Croatia enables politicians to censor expert reports (for example, the report on GHG emissions; another example is the government's rejection of the Ombudsman's special report on the 2014 flood crisis).

However, in both Croatia and Serbia, some interviewees say that the government capacities to create better climate policy are growing. Interviewees in all three countries recognize that climate change issues fall in the background of the current economic and political crises in their countries, which creates high unemployment rates and increases vulnerability. This is illustrated in the next quotation:

B5: "There is a serious lack of will and interest, all is subdued to economic development and new jobs because unemployment is so high here... so, there is no interest in introducing additional setbacks which could come through climate politics."

The thematic domain "flood crisis management" holds 10 sub-codes that form a network through which interviewees answered questions about their perception of the flood crisis management and (political) consequences that the crisis had in each country. This domain holds most sub-codes that overlap with interviewees' perspectives on climate change, namely those sub-codes through which the adaptation theme is interpreted, as well as sub-codes that refer to direct answers about the impact the 2014 floods had on climate policy. 
Table 2. Flood crisis management domain: appearance of codes in country

\begin{tabular}{|l|l|}
\hline \multicolumn{1}{|c|}{ CODES } & \multicolumn{1}{|c|}{ APPEARANCE IN COUNTRY } \\
\hline State did not respond adequately to flooding & Bosnia, Croatia, Serbia \\
\hline $\begin{array}{l}\text { State is shifting responsibility for adaptation } \\
\text { on individuals* }\end{array}$ & Croatia \\
\hline Opportunity in crisis* & Bosnia, Croatia, Serbia \\
\hline State responded adequately on flooding & Bosnia, Croatia, Serbia \\
\hline No lessons were learned* & Bosnia, Croatia, Serbia \\
\hline $\begin{array}{l}\text { Flooding was dealt with only through disaster } \\
\text { management, not in the context of climate } \\
\text { change* }\end{array}$ & Bosnia, Croatia, Serbia \\
\hline Floods encouraged new climate policies & Bosnia, Croatia \\
\hline Lack of finance for adaptation & Bosnia, Croatia, Serbia \\
\hline Flood - climate change - calamity connection & Bosnia, Croatia \\
\hline $\begin{array}{l}\text { Extreme weather events as a consequence of } \\
\text { climate change* }\end{array}$ & Bosnia, Croatia, Serbia \\
\hline
\end{tabular}

* Codes that refer to climate adaptation policy - where the climate policy domain and flood crisis management domain overlap

When asked if they see any (and if so, which) manifestations of climate change, the majority of interviewees answered that they have been noticing more extreme weather events, such as floods and droughts. Some interviewees differentiated between the extreme weather events as either a consequence of climate change or the negative ways in which resources are managed (for example, water management and forestry), which contributes to an increase in vulnerability (Cannon, 2006).

H9: "Yes, I see the connection between flooding and climate change, but what happened in Gunja was also due to human error, because the embankment broke... and that could have been avoided, and the consequences wouldn't be so tragic."

When asked further questions about their perception of the 2014 flood crisis, the answers start to differ, but only at first glance. Not surprisingly, some interviewees thought the state did everything it possibly could have done at the given moment, while others thought not nearly enough was done to help the casualties. In both cases, interviewees were talking about disaster management in their country, without further consequences in mind, or a broader context of climate policy in their country. Also, the interviewees who felt like nothing more could have been done were mostly (not exclusively) talking about urgent measures and on-the-spot organization (for example, in case of evacuation); on the other hand, interviewees who thought state bodies did not do enough were mostly (not exclusively) talking about subsequent care for the casualties, the restructur- 
ing program, or prevention possibilities. We demonstrate this contradiction through the following quotations:

H2: "Given the circumstances, the state gave a good response... really there were only three cases of death. I'm talking about risk management, about urgent measures... And since they did not see them [floods] coming, they managed just fine..."

H3: "The issue of former subtenants remains unsolved. After the houses were rebuilt, the owners raised the rent fees... and also some houses aren't being rebuilt because of unsolved property rights..."

There were also differences in perceptions when interviewees were asked about whether the flood crisis had any impact on climate policy, or if there was some "learning effect" after the floods that can be seen through certain measures. Some interviewees think that the floods had no effect on the development of climate policy, others that it has had a certain effect. Although those attitudes may seem opposite, sometimes they are complementary, as we will further explain. Both sub-codes ("no lessons were learned" and "floods encouraged new climate policies") are associated with another perception that decision makers dealt with the flood crisis only through disaster management and that there were no links with climate policy, or that the flood crisis had any effect on it. Although we could associate the latter with "no lessons were learned" code, it can also be connected with the view that there were some improvements in the policies, because interviewees that shared the latter view were generally talking about improvements in disaster management, or (in the case of Croatia) about the new infrastructure projects of rebuilding embankments. Thus, there was no real effect on climate policy, only certain partial improvements in the disaster management department. Having this and the difference between transformational and incremental adaptation in mind (Kates et al., 2012), we can say that in this case there is no transformational adaptation that would, through scope and type of change, change the whole system making it more resilient. What interviewees are reporting is a case of incremental adaptation that applies to smaller extensions of existing defense measures.

Most of the interviewees believe that there was an opportunity in the crisis; namely through learning from previous mistakes and by creating a climate policy that would contribute to overall society development, not only to adaptation capacities, as is illustrated in the following quotations:

B3: "Really, these kinds of tragedies are an opportunity to start over. The casualties literally had to start from scratch because they lost everything. But that could be a new start for the whole community, to develop, and the state should have also learnt something from it."

S2: "There is not enough awareness that something that is a 'bitter bite' could be a gain in the long run. There is an infinite range of measures that can be low cost and effective at the same time."

Regarding the latter, there is certain potential for transformative adaptation, at least in the aspect of interviewees' recognition of the possibility for implementation of broader 
adaptation measures that could transform the entire community for the better. On the other hand, institutional and behavioral obstacles, such as social and legal perception of rights, resources allocation, policies and cultural norms (Kates et al., 2012) are preventing such implementation for the time being.

Finally, some interviewees had something to say about the state-owned firms in charge of managing resources like water and forests. Although the question about public and private sector roles was not included in the interview, some interviewees imposed this subject of their own accord, since some public and private firms were included in the direct and indirect response to the catastrophe, mostly through humanitarian work, namely financial donations. The thematic domain "Public/ private sector's role" holds 5 sub codes.

Table 3. Public / private sector's role domain: appearance of codes in country

\begin{tabular}{|l|l|}
\hline \multicolumn{1}{|c|}{ CODES } & \multicolumn{1}{|c|}{ APPEARANCE IN COUNTRY } \\
\hline Blue wash & Croatia \\
\hline Green wash & Bosnia, Croatia \\
\hline $\begin{array}{l}\text { Industry has no interest in monitoring climate } \\
\text { change impacts }\end{array}$ & Bosnia, Croatia, Serbia \\
\hline $\begin{array}{l}\text { Public and private sectors do not recognize the } \\
\text { impact of climate change }\end{array}$ & Croatia, Serbia \\
\hline
\end{tabular}

Some interviewees in Bosnia and Herzegovina and Croatia noticed "blue" or "green wash" in some public companies' policies; interviewees had the notion that the 2014 floods were seen as a good opportunity for some companies to portray themselves to the public as humanitarian and / or environment-friendly.

H1: "They [firms] have bragged for the next two years in their reports about how much money or food they donated. Ok, we have that solidarity trait... but our firms will gladly do humanitarian work when it's convenient. [...] on the other hand they declare it as socially responsible work, which is not true."

Some interviewees also perceive the public / private sector as not having interest in monitoring the climate change impact, and therefore not recognizing the impact climate change has on their businesses.

However, those themes / codes are only seldom and briefly mentioned by a few interviewees (see Table 6 in Appendix 1), and have no explanatory power, do not fulfill the criteria of groundedness and / or density, and therefore have no analytical connection to other thematic domains. With that in mind, it would be incorrect to draw any further conclusions based on those codes.

\subsection{Discussion}

Although most interviewees are aware there is a connection between climate change and the 2014 floods (and other extreme weather), not all of them are able to perceive how 
climate policy should deal with those kinds of crises. This can be ascribed to the lack of comprehensive climate policy in each country (especially in Bosnia and Herzegovina and Serbia), but also to the sampling that was conditioned by the ministry and administrative structure, which will be explained later.

Besides the obvious differences in climate policy coverage between the countries (Croatian policy being the most extensive since Croatia is a EU member), part of the relevant stakeholders that we interviewed would agree that the 2014 floods (or other extremes, like droughts) were not dealt with through climate policy; moreover, some would even say there is no consistent and effective climate policy at all. This is interesting considering that some of our interviewees take part in the creation of measures that are considered to be a part of climate policy. The interviewees also revealed (through their answers) that they are not fully aware of the difference between disaster management and bringing disaster management closer to climate policy (adaptation). This might explain the differences in perception of state effectiveness in dealing with the 2014 flood crisis, where some interviewees felt that the state reaction was sufficient and effective (talking about urgent measures like evacuation), while others thought the opposite was true (talking about lack of comprehensive resources management in regard to climate change). The absence of an unanimous view on issues such as the role of governance in the 2014 flood crisis, the policy changes that followed, and the failure to understand the differences between climate policy and disaster management could also be explained by the sampling, or to be more exact, the ministry and administrative structure. For the most part, the sample was constructed out of key stakeholders within state administration bodies. Since climate mitigation and adaptation measures are divided between different ministries and departments in all three countries, and are a part of noncomplementary policies, this structural fragmentation is reflected in the interviewees' outlook. The fragmentation, also shown through the failure to understand the difference between disaster management and climate adaptation policy, supports the interviewees' view that no comprehensive and effective climate policy exists.

Here it is important to address the limitations of this research regarding its explanatory potential and broadness of research findings. In that regard it should be noted that it is very likely that there are differences in perceptions among the interviewees regarding their affiliation to different sectors (state or otherwise), which is not completely shown in the research findings. In this particular research, the sampling was not conducted with that kind of analysis in mind since it does not include representatives of different state bodies (ministries and agencies) and / or civil sector equally in all three countries; therefore it would be impossible to compare the different countries a propos the differences / similarities in the perceptions of sector members. Also, conclusions on those (sectoral) differences would require additional multiple comparative analyses among the different sectors and among the different countries, which is beyond the scope of this paper, but it leaves space for additional research on this topic.

We can further note that the research findings show no differences in an actor's reaction / perception on the disaster event itself regarding the scope of damage each country 
suffered, and regarding the different legal framework in each country. This is because the research questions and research aim were not focused on the disaster management process itself, or on the assessment of on-the-spot disaster management regarding the legislative framework in each country. Rather, the aim of the research was focused on the perception actors have on official / state's reaction to extreme events in the context of climate policy, with an emphasis on potential outcomes in improvement of that same policy; in that regard we enclose the interview protocol in Appendix 2 at the end of this paper.

Having answered research questions about whether the 2014 flood crisis brought about any modifications in climate policies and what the obstacles and opportunities for better adaptation measures are, there are still questions that remain unexplored, like the ones mentioned above. To answer those research questions would be especially relevant in the context of official reactions and climate policy advancement in the case of the repeated larger flooding in Bosnia and Serbia that took place in the year 2017.

\section{CONCLUSION}

Even though some research suggests that the impact of climate change in developed countries is postponing learning and activity (Adger et al., 2009), the results of this research point to a different conclusion. The interviewees have expressed concern regarding the consequences of climate change, being fully aware that climate change impact can already be seen in the form of ever more intense and more frequent climate extremes. However, as the scale reveals, there is a lack of the sense of urgency to develop and apply adaptation strategies, which in turn prevents learning about effective adaptation strategies and putting them into practice. On an organizational level, the major issues are the lack of expertise in sector management, institutional fragmentation and difficulties in understanding the impacts of climate change, as well as difficulties in the development of adaptation strategies. In all three countries, the interviewees concluded that there is no comprehensive and efficient climate policy, which is why the barriers to the implementation of mitigation measures can be seen in the limited capacity for creating adaptation strategies. Without a serious attempt at implementation of mitigation measures, a high level of development and implementation of adaptation measures cannot be expected.

We may agree with the conclusions of Ford et al.'s research (2011) which shows that a great barrier to adaption is the lack of political will. There is a considerable gap between nominal support of adaptation strategies on a national level, and the lack of operational activity on the local level. In such cases adaptation comes down to activities concerning short-term risks, instead of long-term strategic planning, which increases vulnerability and hinders future adaptation (Ford et al., 2011).

Efficient adaptation to climate change requires resolute political action. Decision making based on current and future impact of climate change, both on a national and local level, calls for a comprehensive and trans-sectoral climate policy which recognizes the 
need for mitigation as well as adaptation strategies. Successful adaptation to climate change cannot be addressed solely through disaster management; it must act preventively as well, building up the resilience of entire communities through all segments of life.

Acknowledgment: This research was conducted within the RRPP Project on Crisis Management during the floods in Bosnia and Herzegovina, Serbia and Croatia, which was financed by the Regional Research Promotion Programme under the University of Freiburg and Swiss Agency for Development and Cooperation. Data collection was conducted by the author of this paper and Vedran Horvat from the Institute for Political Ecology who also coordinated the research activities.

\section{REFERENCES}

Adger, W. N. (2003). Social Capital, Collective Action, and Adaptation to Climate Change. Economic Geography, 79(4): 387-404.

Adger, N., Dessai, S., Goulden, M., Hulme, M., Lorenzoni, I., Nelson, D., Otto, L., Naess, J. and Wreford, A. (2009). Are there social limits to adaptation to climate change? Climatic Change, 93(3-4): 335-354.

Brooks, N. (2003). Vulnerability, risk and adaptation: A conceptual framework. Tyndall Centre for Climate Change Research. Working Paper 38. URL: https://www.researchgate.net/publication/200032746_Vulnerability_Risk_and_Adaptation_A_ Conceptual_Framework (15.09.2018.)

Cardona, O. D., van Aalst, M. K., Birkmann, J., Fordham, M., McGregor, G., Perez, R., Pulwarty, R. S., Schipper, E. L. F., Sinh, B.T., Decamps, H., Keim, M., Davis, I., Ebi, K. L., Lavell, A., Mechler, R., Pelling, M., Pohl, J., Oliver-Smith, A. and Thomalla, F. (2012). Determinants of risk: Exposure and vulnerability. In: Field, C. B., Barros, V. Stocker, T. F., Qin, D., Dokken, D. J., Ebi, K. L., Mastrandrea, M. D., Mach, K. J., Plattner, G. K., Allen, S. K., Tignor, M. and Midgley, P. M. (eds.), Managing the Risks of Extreme Events and Disasters to Advance Climate Change Adaptation (pp. 65-108). Cambridge: Cambridge University Press.

Cannon, T. (2006). Vulnerability analysis, livelihoods and disasters. In: Ammann, W. J., Dannenmann, S. and Vulliet, L. (eds.), Risk 21: Coping with Risks Due to Natural Hazards in the 21st Century (pp. 41-49). London: Taylor and Francis Group.

Chandler, D. (2014). Beyond neoliberalism: resilience, the new art of governing complexity. Resilience: International Policies, Practices and Discourses, 2(1): 47-63.

Charmaz, K. (2000). Grounded Theory - Objectivist and Constructivist Methods. In: Denzin, N. K. and Lincoln, Y. S. (eds.), Handbook of Qualitative Research (pp. 509532). London: Sage publications.

Corbin, J. and Strauss, A. (1990). Grounded Theory Research: Procedures, Canons, and Evaluative Criteria. Qualitative Sociology, 13(1): 3-21.

Davoudi, S. (2012). Resilience: A Bridging Concept or a Dead End? Planning Theory \& Practice, 13(2): 299-333. 
Few, R., Brown, K. and Tompkins, E. L. (2007). Public participation and climate change adaptation: avoiding the illusion of inclusion. Climate Policy, 7(1): 46-59.

Ford, J., Berrang-Ford, L. and Paterson, J. (2011). A systematic review of observed climate change adaptation in developed nations. Climatic Change, 106(2): 327-336.

Füssel, H., M. (2007). Adaptation Planning for Climate Change: Concepts, Assessment Approaches, and Key Lessons. Sustainability Science, 2(2): 265-275.

Giddens, A. (2009). The Politics of Climate Change. Cambridge: Polity Press.

Grove, K. and Chandler, D. (2016). Introduction: resilience and the Anthropocene: the stakes of 'renaturalising' politics. Resilience: International Policies, Practices and Discourses, 5(2): 79-91.

Parry, M. L., Canziani, O. F., Palutikof, J. P., van der Linden P. J. and Hanson, C. E. (eds.), (2007). Climate change 2007: Impacts, Adaptation and Vulnerability. Contribution of Working Group II to the Fourth Assesment Report of the Intergovernmental Panel on Climate Change. Cambridge: Cambridge University Press.

Stocker, T. F., Qin, D., Plattner, G. K., Tignor, M. M. B., Allen, S. K., Boschung, J., Nauels, A., Xia, Y., Bex, V., and Midgley, P. M. (eds.) (2013). Climate Change 2013: The Physical Science Basis. Contribution of Working Group I to the Fifth Assessment Report of the Intergovernmental Panel on Climate Change. Cambridge: Cambridge University Press.

Jongman, B., Hochrainer-Stigler, S., Feyen, L., Aerts, J. C. J. H., Mechler, R., Wouter Botzen, W. J., Bouwer, L. M., Pflug, G., Rojas, R. and Ward, P. J. (2014). Increasing stress on disaster-risk finance due to large floods. Nature Climate Change, 4: 264-268.

Kates, R., Travis, W. and Wilbanks, T. (2012). Transformational adaptation when incremental adaptations to climate change are insufficient. Proceedings of National Academy of Science of United States of America, 109(19): 7156-7161.

Mercer, J. (2010). Disaster risk reduction or climate change adaptation: are we reinventing the wheel? Journal of International Development, 22(2): 247-264.

Mirza, M. Q. (2003). Climate change and extreme weather events: can developing countries adapt? Climate Policy, 3(3): 233-248.

Moser, S. and Ekstrom, J. (2010). A framework to diagnose barriers to climate change adaptation. Proceedings of the National Academy of Science of United States of America, 107(51): 22026-22031.

Nkoana, E. M., Verbruggen, A. and Hugé, J. (2018). Climate Change Adaptation Tools at the Community Level: An Integrated Literature Review. Sustainability, 10(3). DOI: $10.3390 /$ su10030796.

O'Brien, K. L. and Leichenko, R. M. (2003). Winners and Losers in the Context of Global Change. Annals of the Association of American Goegraphers, 93(1): 89-103.

O'Brien, G., O'Keefe, P., Rose, J. and Wisner, B. (2006). Climate change and disaster management. Disasters, 30(1): 64-80.

Shaw, K. (2012). "Reframing" Resilience: Challenges for Planning Theory and Practice. Planning Theory \& Practice, 13(2): 308-312. 
Thomalla, F., Downing, T., Spanger-Siegfried, E., Han, G. and Rockström, J. (2006). Reducing hazard vulnerability: towards a common approach between disaster risk reduction and climate adaptation. Disasters, 30(1): 39-48.

Turner, B., L., Matson, P., A., McCarthy, J., Corell, R. W., Christensen, L., Eckley, N., Hovelsrud-Broda, G. K., Kasperson, J. X., Kasperson, R. E., Luers, A., Martello, M. L., Mathiesen, S., Naylor, R., Polsky, C., Pulsipher, A., Schiller, A., Selin, H., and Tyler, N. (2003). Illustrating the coupled human-environment system for vulnerability analysis: Three case studies. Proceedings of the National Academy of Sciences of the United States of America, 100(14): 8080-8085.

Župarić-Iljić, D. (2017). Environmental Change and Involuntary Migration: Environmental Vulnerability and Displacement Caused by the 2014 Flooding in South-Eastern Europe. In: Domazet, M. (ed.), Ecology and Justice: Contributions from the margins (pp. 137-164). Zagreb: Institute for Political Ecology. 
Appendix 1.

Codes-Primary documents tables:

Table 4. Climate policy

\begin{tabular}{|l|c|c|c|}
\hline \multicolumn{1}{|c|}{ CODES } & Bosnia & Croatia & Serbia \\
\hline Public department inertness & 3 & 7 & 2 \\
\hline Influence of infrastructural projects & 3 & 3 & 0 \\
\hline Corruption & 5 & 4 & 2 \\
\hline Economic and political crisis & 4 & 3 & 4 \\
\hline Negative selection in public administration & 2 & 4 & 1 \\
\hline There is no climate policy & 2 & 4 & 0 \\
\hline Poor human capacities & 4 & 6 & 5 \\
\hline Lack of integrative approach & 4 & 8 & 6 \\
\hline Incompatibility of key documents & 0 & 6 & 2 \\
\hline Political censorship & 0 & 3 & 0 \\
\hline Politics doesn't use science & 5 & 4 & 3 \\
\hline Need for separate department for climate policy & 2 & 4 & 2 \\
\hline Problems on local level & 4 & 7 & 5 \\
\hline Growing government capacities for climate policy & 0 & 5 & 3 \\
\hline International influences & 5 & 6 & 4 \\
\hline Public interest negligence & 0 & 4 & 0 \\
\hline
\end{tabular}

Table 5. Flood crisis management

\begin{tabular}{|l|c|c|c|}
\hline \multicolumn{1}{|c|}{ CODES } & Bosnia & Croatia & Serbia \\
\hline State did not respond adequately to flooding & 4 & 7 & 2 \\
\hline $\begin{array}{l}\text { State is shifting responsibility for adaptation } \\
\text { on individuals }\end{array}$ & 0 & 1 & 0 \\
\hline Opportunity in crisis & 4 & 8 & 3 \\
\hline State responded adequately on flooding & 3 & 5 & 3 \\
\hline No lessons were learned & 5 & 6 & 4 \\
\hline $\begin{array}{l}\text { Flooding was dealt with only through disaster } \\
\text { management, not in the context of climate change }\end{array}$ & 4 & 2 & 3 \\
\hline Floods encouraged new climate policies & 3 & 5 & 1 \\
\hline Lack of finance for adaptation & 4 & 3 & 1 \\
\hline Flood - climate change - calamity connection & 3 & 5 & 0 \\
\hline
\end{tabular}


Extreme weather events as a consequence of climate change

4

9

4

Table 6. Public / private sector's role

\begin{tabular}{|l|c|c|c|}
\hline \multicolumn{1}{|c|}{ CODES } & Bosnia & Croatia & Serbia \\
\hline Blue wash & 0 & 4 & 0 \\
\hline Green wash & 2 & 3 & 0 \\
\hline $\begin{array}{l}\text { Industry has no interest in monitoring climate } \\
\text { change impacts }\end{array}$ & 2 & 4 & 2 \\
\hline $\begin{array}{l}\text { Public and private sectors do not recognise the } \\
\text { impact of climate change }\end{array}$ & 0 & 2 & 2 \\
\hline
\end{tabular}

\section{Appendix 2.}

\section{Interview protocol:}

1. How do you assess the development of climate policy in the country during the last decade? What were the decisive processes at the international / European / domestic level which influenced the direction of climate policy?

2. What do you see as the greatest challenges for the climate policy in the country? Which sectors are mainly affected by climate change?

3. How do you assess the analytical capacity of the state to use climate science in respective scenarios for adaptation to climate change?

4. To which extent are the climate and energy policy in your country "in tune"?

5. How do you assess the coordination between your agency and other agencies which are accountable for some aspects of the climate policy?

6. How do you see the division of work and responsibilities at the state level concerning climate protection?

7. Where do you see the manifestation of climate change?

8. Was your organisation involved in any way during the flood crisis? How?

9. Is your institution involved in adaptation / prevention of floods (at any level)?

10. Do you see a clear link between damage generated by floods and climate change impacts?

11. Do you think that the event of floods in the region had any impact on climate policy in the country? If not, why is this missing?

12. Do you see current measures against the floods resilient to climate change? Do you think relevant climate science literature has been consulted? 


\title{
(NE)NAUČENE LEKCIJE IZ POLITIKE PRILAGODBE KLIMATSKIM PROMJENAMA: KVALITATIVNO ISTRAŽIVANJE POPLAVA U DRŽAVAMA ZAPADNOG BALKANA
}

\author{
Jelena Puđak
}

\begin{abstract}
Sažetak
U ovom radu donosimo rezultate kvalitativnog istraživanja o prilagodbi klimatskim promjenama u kontekstu velikih poplava koje su pogodile zemlje srednje i jugoistočne Europe 2014. godine. Pod prilagodbom se misli na odgovor društvenih institucija na postojeće ili očekivane posljedice klimatskih promjena i ekstremnih klimatskih pojava. Učinkovitost odgovora ovisi o tome koliko je sustav otporan, odnosno ranjiv te je ovisna ne samo o tehničkim i biofizičkim aspektima, već i društvenim, kulturnim, političkim i ekonomskim. Empirijsko je istraživanje provedeno da bi se utvrdilo kako akteri koji upravljaju odlukama vezanima za okoliš u trima zemljama, Bosni i Hercegovini, Hrvatskoj i Srbiji, percipiraju proces prilagodbe klimatskim promjenama, te jesu li klimatske promjene bile prepoznate kao nadsektorski problem tijekom različitih faza krize vezane za poplave 2014. godine. Rezultati pokazuju da iako je većina ispitanika svjesna povezanosti izmedu klimatskim promjena i poplava 2014. godine, nisu uspjeli ispravno odgovoriti na nastalu krizu. U sve tri zemlje, mjere ublažavanja i prilagodbe razjedinjene su između nekoliko razlicitih ministarstava i odjela koji nisu međusobno povezani, o čemu govore $i$ ispitanici.
\end{abstract}

Ključne riječi: klimatske promjene, prilagodba, kvalitativno istraživanje, zapadni Balkan

\section{(UN)GELERNTE LEKTIONEN AUS DER POLITIK DER ANPASSUNG AN DEN KLIMAWANDEL: QUALITATIVE UNTERSUCHUNG DER ÜBERSCHWEMMUNGEN IN DEN LÄNDERN DES WESTBALKANS}

\author{
Jelena Puđak
}

\begin{abstract}
Zusammenfassung
Im vorliegenden Artikel präsentieren wir die Ergebnisse der qualitativen Untersuchung über die Anpassung an den Klimawandel im Zusammenhang mit großen Überschwemmungen, von denen die Länder des Mittel- und Südosteuropas im Jahr 2014 betroffen wurden. Unter der Anpassung ist hier die Reaktion der Behörden auf die bestehenden oder die zu erwartenden Folgen des Klimawandels und der extremen Klimaerscheinungen gemeint. Die Effizienz der Reaktion hängt davon ab, in welchem Ausmaß das System widerstandsfähig bzw. vulnerabel ist, sie ist nicht nur von technischen und biophysischen, sondern auch von sozialen, kulturellen, politischen und ökonomischen Aspekten abhängig. Eine empirische Untersuchung wurde durchgeführt, um zu zeigen, wie die Akteure in den Strukturen der Umweltverwaltung in Bosnien und Herzegowina, Kroatien und Serbien den Prozeß der Anpassung an den Klimawandel perzipieren und ob der Klimawandel als ein sektorenübergreifendes Problem während verschiedener Phasen der mit Überschwemmungen aus dem Jahr 2014 verbundenen Krise anerkannt wurde. Die Ergebnisse zeigen, dass sich die meisten Befragten der Verbindung zwischen dem Klimawandel und den Überschwemmungen aus dem Jahr 2014 bewusst sind, jedoch nicht im Stande waren, auf die entstandene Krise richtig zu reagieren. In allen drei Ländern sind die Kompetenzen über Maßnahmen zur Milderung und Anpassung unter verschiedenen miteinander nicht verbundenen Ministerien und Abteilungen verteilt, wie die Befragten aussagten.
\end{abstract}

Schlüsselwörter: Klimawandel, Anpassung, qualitative Untersuchung, Westbalkan 